\title{
EARLY HOLOCENE LONG-DISTANCE OBSIDIAN TRANSPORT IN CENTRAL-SOUTH PATAGONIA
}

\author{
TRANSPORTE DE LARGA DISTANCIA DE OBSIDIANAS EN PATAGONIA \\ CENTRO-SUR DURANTE EL HOLOCENO TEMPRANO
}

\author{
César A. Méndez M. ${ }^{1}$, Charles R. Stern ${ }^{2}$, Omar R. Reyes B. ${ }^{3}$ and Francisco Mena L. ${ }^{4}$
}

\begin{abstract}
Chronological based data for Early Holocene obsidian transport is not abundant for sites in continental Patagonia. We present ICP-MS analyses of obsidian samples from two well-dated stratified cave archaeological deposits in the steppe plains of the Aisén region (Chile) and discuss the implications of this data for constraining temporal trends in technological decisions related to huntergatherers mobility and use of space. The evidence presented suggests that recurrent obsidian circulation routes were established in central-south Patagonia at the onset of the Holocene.
\end{abstract}

Key words: Obsidian transport, ICP-MS, Patagonia, Early Holocene.

Los datos con fundamento cronológico para el transporte de obsidiana durante el Holoceno Temprano en Patagonia continental son escasos. Presentamos análisis de ICP-MS en muestras de obsidiana de dos depósitos arqueológicos estratificados bien fechados bajo reparo en las planicies esteparias de la región de Aisén (Chile) y discutimos las implicancias de estos datos para precisar las tendencias temporales de las decisiones tecnológicas relacionadas a la movilidad y uso del espacio de cazadores recolectores. La evidencia presentada sugiere que fue con el inicio del Holoceno que las rutas recurrentes de circulación de obsidianas se establecieron en Patagonia centro sur.

Palabras claves: transporte de obsidiana, ICP-MS, Patagonia, Holoceno Temprano.

In Patagonia (southernmost South America) there is a significant amount of geochemical obsidian sourcing data which has identified available sources and provided a great deal of information for discussing the spatial scale of prehistoric transport of high-quality obsidian throughout the region (Barberena et al. 2010; Belardi et al. 2006; Civalero and Franco 2003; Favier Dubois et al. 2009; García-Herbst et al. 2007; Méndez 2004; Méndez et al. 2008-9; Molinari and Espinosa 1999; Morello et al. 2004; Stern 1999, 2004; amongst many others). South of $42^{\circ} \mathrm{S}$, a total of six sources have been recognized as systematically exploited and their obsidians widely transported (Figure 1). These include translucent grey obsidian from Chaitén volcano (Stern et al. 2002); black and translucent grey-black obsidians from Sacanana and Sierra Negra sources in Somuncurá plateau (Gómez Otero and Stern 2005; Stern et al. 2000); green obsidian from Seno Otway (Morello et al. 2001; Stern and Prieto 1991); banded grey-green obsidian from Cordillera Baguales (Stern and Franco 2000) and black obsidian from Pampa del Asador (Espinosa and Goñi 1999; Stern 1999). The latter has been the most recurrently transported lithic raw-material in the region, with exceptionally long-distant movements of more than $800 \mathrm{~km}$ (Stern 2004). As expected, obsidians are not randomly distributed; for instance while Chaitén and Seno Otway obsidian artifacts occur along western archipelagic areas and thus belong broadly, though not exclusively, to the realm of maritime hunter-gatherers of the Pacific (Méndez et al. 2008-9; Morello et al. 2001, 2004), the other four types are basically recorded at continental locations of the steppes of eastern Patagonia and within the forest/steppe transition at the eastern margin of the Andes mountain range (Stern 2004).

1 Departamento de Antropología, Facultad de Ciencias Sociales, Universidad de Chile, Cap. Ignacio Carrera Pinto 1045, Ñuñoa, Santiago, Chile.cmendezm@uchile.cl

2 Department of Geological Sciences, University of Colorado, Boulder, Colorado 80309-0399, USA. charles.stern@ colorado.edu

3 Centro de Estudios del Hombre Austral, Instituto de la Patagonia, Universidad de Magallanes, Av. Bulnes 01890, Punta Arenas, Chile. omarreyesbaez@gmail.com

4 Centro de Investigación en Ecosistemas de la Patagonia, Bilbao 449, Coyhaique, Chile. francisco.mena@ciep.cl 


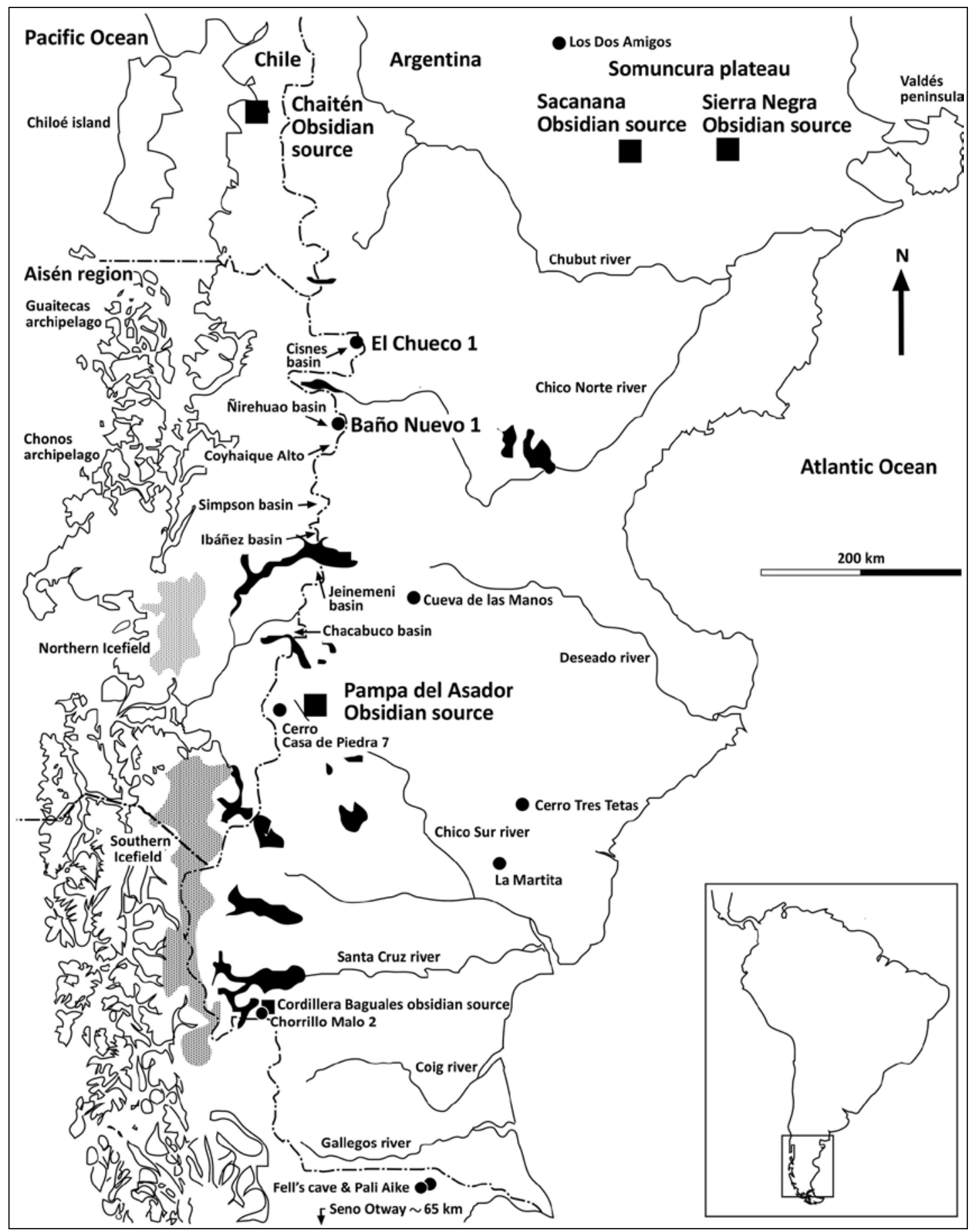

Figure 1. Map of central-south Patagonia and the study area showing well located obsidian sources (large squares); Early Holocene archaeological sites with PDA obsidian type (circles), including the two sites in Aisén discussed in this paper, and river basins in Aisén with surface obsidian evidence.

Mapa de Patagonia centro-sur y el área de estudio mostrando las fuentes de obsidiana precisamente localizadas (cuadrados grandes); sitios arqueológicos del Holoceno Temprano con obsidiana tipo PDA (círculos), incluyendo los dos sitios dentro de Aisén discutidos en el texto y las cuencas de río en Aisén con evidencias superficiales de obsidiana. 
Despite the current knowledge of obsidian transport in the spatial dimension, only few papers have addressed the issue at a temporal scale (e.g. San Román and Prieto 2004; Stern 2000, 2004), this being especially true for the terminal Pleistocene (dates earlier than $10,000{ }^{14} \mathrm{C}$ yr. b.p. or $\sim 11,500$ calendar years before present, cal. yr. b.p.) and the Early Holocene (10,000 to $8,000{ }^{14} \mathrm{C}$ yr. b.p., or $\sim 11,500$ to $8,800 \mathrm{cal}$. yr. b.p.), time periods for which ${ }^{14} \mathrm{C}$-based records with chemically identified obsidian are infrequent in continental Patagonia. One debitage sample from a >12,020 cal. yr. b.p. level at Cerro Tres Tetas (Figure 1) demonstrates a $\sim 200 \mathrm{~km}$ transport of black obsidian east from the Pampa del Asador source (Paunero 2003; Stern 2004). Among the sites with Early Holocene components, Cerro Casa de Piedra 7 (11,100-9,940 cal. yr. b.p.) contains obsidian tools and debitage transported $\sim 40 \mathrm{~km}$ from the same source (Civalero and Franco 2003). At Chorrillo Malo 2 (11,180 cal. yr. b.p.), despite local obsidian from Cordillera Baguales being frequent, one debitage of black obsidian (>260 km from the Pampa del Asador source) was identified (Civalero and Franco 2003). At all of these sites, as in Cueva de las Manos $(10,520$ cal. yr. b.p.) and La Martita (8,850 cal. yr. b.p.) black obsidian has been chemically identified as consistent with types from Pampa del Asador, especially type PDA1 (Stern 1999). Study cases at Fell's cave and Pali Aike, yielding Early Holocene obsidian evidence only at the latter, argue for longer distance transport ( $>500 \mathrm{~km}$ ), possibly, however, interrupted during the mid Holocene (Stern 2000, 2004). Throughout the paper, all ages are discussed in calendar years b.p. and were calibrated with OxCal 4.01 program (Bronk Ramsey 2009) using ShCal04 curve (McCormac et al. 2004) for ages younger than $9,500{ }^{14} \mathrm{C}$ yr. b.p. and IntCal09 curve (Reimer et al. 2009) for older ages.

The scenario described above suggests a significant level of uncertainty when discussing early high-quality rock transport in Patagonia because of the fragmented nature of the archaeological record. Several questions linger. For instance: (1) are surface obsidian assemblages proper means to measure obsidian transport in time, especially those occurring during the Early Holocene? (2) Which sources were the earliest ones to be used consistently? And, (3) were there temporal interruptions in accessing these sources during the Holocene? All these questions have significant implications for understanding the human use of large areas, as seems to be the case for the movements of huntergatherers in central-south Patagonia.

In order to address some of these issues, archaeological research in Northern Aisén region $\left(43^{\circ} 45^{\prime}-49^{\circ} \mathrm{S}\right.$, Chile, central-western Patagonia) has proven of interest for understanding longdistance obsidian transport. The region is located distant from all known high-quality sources, thus all obsidians encountered here should be regarded as exotic (Meltzer 1989). Two recently studied stratified cave sites have yielded recurrent human occupations spanning throughout the Holocene. At El Chueco 1, the earliest human deposit is dated to 11,500 cal. yr. b.p. (Reyes et al. 2007) and at Baño Nuevo 1, the first component starts at 10,870 cal. yr. b.p. (Mena and Stafford 2006). They are both located east of the Andes mountain range, thus directly connected with the known obsidian artifact distributions that occur along the steppes of eastern Patagonia. These sites have produced a significant amount of ${ }^{14} \mathrm{C}$ dates, accurately placing the evidence on a temporal scale. These characteristics make them appropriate candidates for measuring peopling dynamics, and provide especially good datasets for exploring the temporal scale of exotic obsidian artifact distribution. In this paper we present ICP-MS data on obsidian artifacts with known ${ }^{14} \mathrm{C}$-based chronologies for El Chueco and Baño Nuevo sites. Our main goals are to discuss temporal trends in exotic obsidian distributions in Aisén, compare them to previous non- ${ }^{14} \mathrm{C}$-based datasets, and to discuss some implications of our results and those of others when addressing Early Holocene large-scale hunter-gatherers mobility in Patagonia.

\section{Obsidian Artifact Distributions in Aisén}

The Aisén region is characterized by a strong west-east precipitation gradient as consequence of the forced subsidence of the Southern westerly winds and the rainshadow effect produced by the Andes. East of this mountain range, the landscape is composed of extensive sedimentary plains, large lakes and several other glacial and volcanic-origin landforms. As a result of the rainfall gradient, evergreen forests occur in the mountainous west, while open areas to the east are characterized by a cold-dry semiarid climate with steppe vegetation. The available palaeoenvironmental archives for the 
continental area suggest that the most significant climate and landscape changes occurred during the Pleistocene/Holocene transition, and that the current phytogeographical distribution did not vary substantially since the Early Holocene, except for minor fluctuations in the location of the forest/ steppe margins (Markgraf et al. 2007; Reyes et al. 2009; Villa-Martínez et al. 2011).

During the last decade, archaeological research in Aisén has managed to compile a series of obsidian sourcing analyses from locations both along the Pacific coast, and especially inland along the forest/steppe margin and the eastern plains. While most of the plains are located in Argentina, in Aisén (Chile) only small areas near the border exhibit open steppe settings and have concentrated most of the archaeological regional sampling and geochemical analyses. This information, based on surface surveys, was summarized in Méndez et al. (2008-9) and suggested the main lingering issue was to assess whether the incidence of obsidian observed in the archaeological assemblages had a chronological significance, and to what extent could the averaged surface evidence -mainly attributed to the late Holocene- be representative of earlier distributional tendencies.

The main obsidian type represented in Aisén is the black-colored obsidian from Pampa del Asador (4749'S; 7048'W; Figure 1; Stern 1999). Obsidian artifacts in this rock has been observed throughout the eastern rim of the study area (Chacabuco, Jeinemeni, Ibáñez, Simpson, Ñirehuao, and Cisnes basins and Coyhaique Alto area) showing a strong relation between distance increase and frequency reduction in comparable south-to-north ordered samples (Méndez et al. 2008-9). This is consistent with research at a larger scale which has identified different chemical varieties of this obsidian (types PDA1, 2, 3ab; García-Herbst et al. 2007; Stern 1999), all widely distributed, having been transported $>600 \mathrm{~km}$ south, crossing the Magellan strait (Stern 2004 ), and $>800 \mathrm{~km}$ north, south of Valdés peninsula (Gómez Otero and Stern 2005; Stern et al. 2000), thus making this the most frequent exotic rock in central-south Patagonia. However, surface findings in Aisén show that besides Pampa del Asador types, obsidians from Somuncurá plateau also occur, but solely at the northernmost sampled area, in the upper Cisnes river basin. Metaluminous rhyolite obsidian (type S1) from Sacanana (42 ${ }^{\circ} 30^{\prime} \mathrm{S} ; 68^{\circ} 36$ $\mathrm{W}$ ) and peralkaline rhyolite obsidian (type $\mathrm{T} / \mathrm{SC} 1$ ) from Sierra Negra $\left(42^{\circ} 18^{\prime} \mathrm{S} ; 66^{\circ} 36^{\prime} \mathrm{W}\right)$ have been described for this area (Méndez et al. 2008-9). Obsidians from Sacanana have been observed east of the Andean foothills at a distance of 230 $\mathrm{km}$ west of this source (Bellelli and Pereyra 2002; Stern et al. 2011) and in the Atlantic coast at $>380$ $\mathrm{km}$ east of this source (Favier Dubois et al. 2009; Gómez Otero and Stern 2005). Sierra Negra obsidians are represented up to $230 \mathrm{~km}$ east of this source along the Atlantic coast (Favier Dubois et al. 2009; Gómez Otero and Stern 2005). The upper Cisnes basin is $325 \mathrm{~km}$ distant from Sacanana and $460 \mathrm{~km}$ from Sierra Negra, and corresponds to the current south-westernmost limit of distribution of obsidian artifacts from these sources (Méndez et al. 2008-9).

One other common obsidian in Aisén is grey colored obsidian derived from the Chaitén volcano (Figure 1). However, this type is only recorded at the Pacific coast, west of the Andes, which seems to have acted as an effective population barrier, limiting considerably interaction between peoples to the west and east, respectively (Méndez and Reyes 2008). Besides, no evidences have been found in stratigraphical contexts and all available ${ }^{14} \mathrm{C}$ ages for the coast are yet limited to the last 1,800 cal. yr. b.p. (Méndez et al. 2010). Finally, the only local obsidian type in Aisén corresponds to a highly-brittle variety described for the upper Cisnes river basin (type CIS), whose poor knapping quality limited its prehistoric use considerably (Méndez et al. 2008-9).

Excavating and sampling sites in Aysén with multiple occupations, especially those located where the distribution of obsidians artifacts transported from Somuncurá plateau and obsidian from Pampa del Asador meet, should provide data for assessing continuity and change in long-distance exotic rock transport. If earlier occupations at Cisnes basin included northern and southern types that would imply that surface assemblages -roughly attributed to the latest human presence- are a relatively reliable measure of earlier obsidian artifact distributions. Also, this could suggest two non-mutually exclusive implications: a) the distance factor played a key-role in determining obsidian transport independently of time, and b) once a high-quality desirable raw material was recognized by a group, it would be likely to continue its use, thus generating recurrent mobility and/or exchange networks. 


\section{The Sites}

El Chueco 1 site is located in the steppe plains of the upper Cisnes river basin $\left(44^{\circ} 29^{\prime} 36^{\prime \prime} \mathrm{S}\right.$; 71'11'13'"W; 914 masl), in a cave within a welded rhyolite tuff outcrop surrounded by a moraine (Reyes et al. 2007). Excavations within the cave $\left(16 \mathrm{~m}^{2}\right)$, revealed an ordered and continuous depositional sequence mainly composed by roof-fall particles. A total of $14{ }^{14} \mathrm{C}$ ages were used in defining six components starting with a significantly discrete event at 11,500 cal. yr. b.p., and continuing with successive low-impact occupational events with dated ranges between: 10,180-9,890; 9,230-7,700; 6,930-6,780; 5.520-5,400, and 3,180-2,570 cal. yr b.p. (Méndez et al. 2011). The main features at the site include a series of 14 hearths and charcoal concentrations which are associated to very few lithic artifacts; mainly formal tools on high-quality siliceous rocks (Table 1). Bones are restricted to the upper levels, starting at $\sim 7,000$ cal. yr. b.p. and are dominated by guanaco (Lama guanicoe), the largest available ungulate in the region. The occupational events have been interpreted as characteristic of the recurrent use of marginal environments, possibly in a seasonal basis (Méndez et al. 2011). Locally derived Cisnes (CIS) obsidian occurs naturally at this site as low quantity small nodules within the stratigraphic unit; however excessive brittleness makes this rock unfit for knapping, and thus its use is significantly restricted (Méndez et al. 2008-9). Evidence of other exotic obsidians is very limited, yet present at the site; thus inferences about regional patterning should be regarded as preliminary until new data is available.

Baño Nuevo 1 is a cave located in one of several basaltic buttes that stand out above an extensive plain

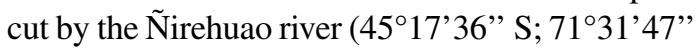
W; 750 masl). As El Chueco, it is surrounded by steppe vegetation and also located near the ChileanArgentinean border. Excavations $\left(25.13 \mathrm{~m}^{2}\right)$ revealed an ordered and continuous depositional sequence. A selection of $31{ }^{14} \mathrm{C}$ ages was used in defining three anthropogenic components: early 10,870-9,460 cal. yr. b.p., middle $8,770-5,820$ cal. yr. b.p., and late 4,660-2,890 cal. yr. b.p. (Mena et al. 2000; Mena and Stafford 2006). Besides its stratigraphic integrity, the site is characterized by stable and low humidity and temperature, allowing the survival of a wide array of organic remains, which includes a ten-individual funerary context directly dated between 10,200-9,700 cal. yr. b.p. A significantly rich bone assemblage characterizes the occupations, guanaco being the most frequent taxa, although other ungulates as huemul (Hippocamulus bisulcus) and a wide diversity of birds occur (Mena 2009; Velásquez and Mena 2006). Lithic material at the site was identified through all the sequence, and is comprised primarily by debitage $(87.9 \%)$ and a small frequency of formal $(3.3 \%)$ and informal (5.3\%) tools (García 2007; Table 1). On the basis of the XRF analysis on one obsidian sample from the lowermost layers (Stern 1999) and macroscopical observations, García (2007) suggested that the only exotic rock was black obsidian from Pampa del Asador, which is especially represented in the middle and late components of the site.

Table 1. Characteristics and data discussed for El Chueco and Baño Nuevo sites (data from stratigraphic samples). *Only debitage.

Características y datos discutidos para los sitios El Chueco y Baño Nuevo (datos de conjuntos estratigráficos). ** Sólo desechos de talla.

\begin{tabular}{lcc}
\hline & El Chueco & Baño Nuevo \\
\hline \# of components (\# of ${ }^{14}$ C ages) & $6(14)$ & $3(31)$ \\
Total lithics & 88 & 1609 \\
Obsidian frequency $\left.*^{*}\right)$ & $4(4.5 \%)$ & $163(10.1 \%)$ \\
General ratio tools/debitage & $0.49(29 / 59)$ & $0.1(148 / 1461)$ \\
Obsidian ratio tools/debitage & $0.33(1 / 3)$ & $0.04(6 / 157)$ \\
Distance to Pampa del Asador source & $360 \mathrm{~km}$ & $290 \mathrm{~km}$ \\
Distance to Sierra Negra source & $460 \mathrm{~km}$ & $500 \mathrm{~km}$ \\
\hline
\end{tabular}




\section{Methods}

Thirty obsidian samples from Baño Nuevo and six samples from El Chueco were selected from archaeological deposits with known ${ }^{14} \mathrm{C}$-based time frames. Additionally we included five natural obsidian nodules from the latter. Either direct ages or ranges were assigned based on the specific location of the samples within the excavation, with higher precision for those artifacts near dated features, than those within stratigraphic packages with known upper and lower temporal limits. Though color and translucency were recorded for all samples, these criteria were not used in selecting for geochemical analyses based on previous regional experiences that suggest they may not be reliable indicators. Table 2 presents chronological and archaeological information coupled to obsidian types identified and selected chemical elements and Table 3 includes geochemical data on local CIS type obsidian nodules recorded at El Chueco site.

Geochemical characterization of these samples was performed at the Laboratory for Environmental Geochemistry at the University of Colorado (Boulder). The samples were ground into a fine powder and dissolved in a weak solution of HF and $\mathrm{HCl}$. Their trace-element contents were determined by ICP-MS (Inductively Coupled Plasma Mass Spectrometry) using an ELAN DCR-E instrument. U. S. Geological Survey standards were used as the calibration standards, and also to monitor accuracy during ICP-MS analysis (Saadat and Stern 2011). Based on repetitive analysis of these U.S.G.S and other internal laboratory rhyolite standards the obsidian trace-element compositions presented in tables 2 and 3 are considered precise to $\pm 10 \%$ at the concentration levels at which they occur (a few parts-per-million). Since obsidian from all the discussed sources in Patagonia south of $42^{\circ} \mathrm{S}$ have also been analyzed with this same method and in this same laboratory, assignation to individual types is highly reliable. Average compositions of these obsidians are presented in Table 4 . The 2 sigma variability of these average compositions are also approximately $\pm 10 \%$, that is essentially within analytical uncertainty, reflecting the fact that the obsidian from these sources are very homogeneous in composition (details are provided in Stern 2000). Analyses on samples from unknown sources were replicated with similar results.

\section{Results}

Obsidian types identified at El Chueco and Baño Nuevo sites are summarized in Table 5 and Figure 2. Most of the samples fall in the fields for obsidian from known sources (PDA1, PDA2, PDA3ab, CIS, and T/SC1), with these fields taken from previously published data (Mendez et al. 2008-9; Stern 1999, 2004; Stern et al. 2000), while five samples are from unknown (UK) sources. One of these 5 samples overlaps the field of PDA1 with respect to Ba and $\mathrm{Zr}$, and 2 overlap the field of PDA3ab, but these samples are otherwise chemically different from these known obsidian types with lower $\mathrm{Sr}$ content and other differences (Tables 2 and 4).

For El Chueco site, obsidians include local Cisnes (CIS) type as natural (unflaked) nodules and only two pieces of debitage. Two other small obsidian flakes recorded within the $10,180 \mathrm{cal}$. yr. b.p. level are identified as exotic obsidians, one from Pampa del Asador (PDA 1 type) and one possibly from the Sierra Negra source. This latter sample is very similar to $\mathrm{T} / \mathrm{SC} 1$ and $\mathrm{T} / \mathrm{SC} 2$ obsidian types with respect to $\mathrm{Ba}, \mathrm{Sr}, \mathrm{Zr}, \mathrm{Y}, \mathrm{Hf}$, Th, and rare-earthelements, and therefore considered derived from this same source. However this sample shows lower $\mathrm{Rb}$ and $\mathrm{Nb}$ contents than either types $\mathrm{T} / \mathrm{SC} 1$ and $\mathrm{T} / \mathrm{SC} 2$ and thus is not definitively attributable to either one of these two particular types of Sierra Negra obsidian, for which reason we refer to it as T/SC? One highly-curated bifacial point, showing several reutilized edges, and dating to 5,520 cal. yr. b.p., was also identified as PDA1 type (Figure 3).

Previously, geochemical analyses on surface obsidian samples within a $13 \mathrm{~km}$ radius from $\mathrm{El}$ Chueco identified PDA1, T/SC1, and S1 types at sites with latest Holocene occupations (roughly the last 1,500 cal. yr. b.p.; Méndez et al. 2008-9). These samples showed late stages in the reduction sequence of obsidian (mainly small retouch debitage), as is always the case for obsidian from El Chueco. The spatial coexistence of exotic raw materials from both one of the northern sources at Somuncurá plateau and from the southern source at Pampa del Asador -at least during two different moments (early and latest Holocene)- suggests similar mobility ranges and/or indirect acquisition practices including sources $>360 \mathrm{~km}$ distant. On the other hand, the poor knapping quality of local Cisnes obsidian has resulted in a significantly low 


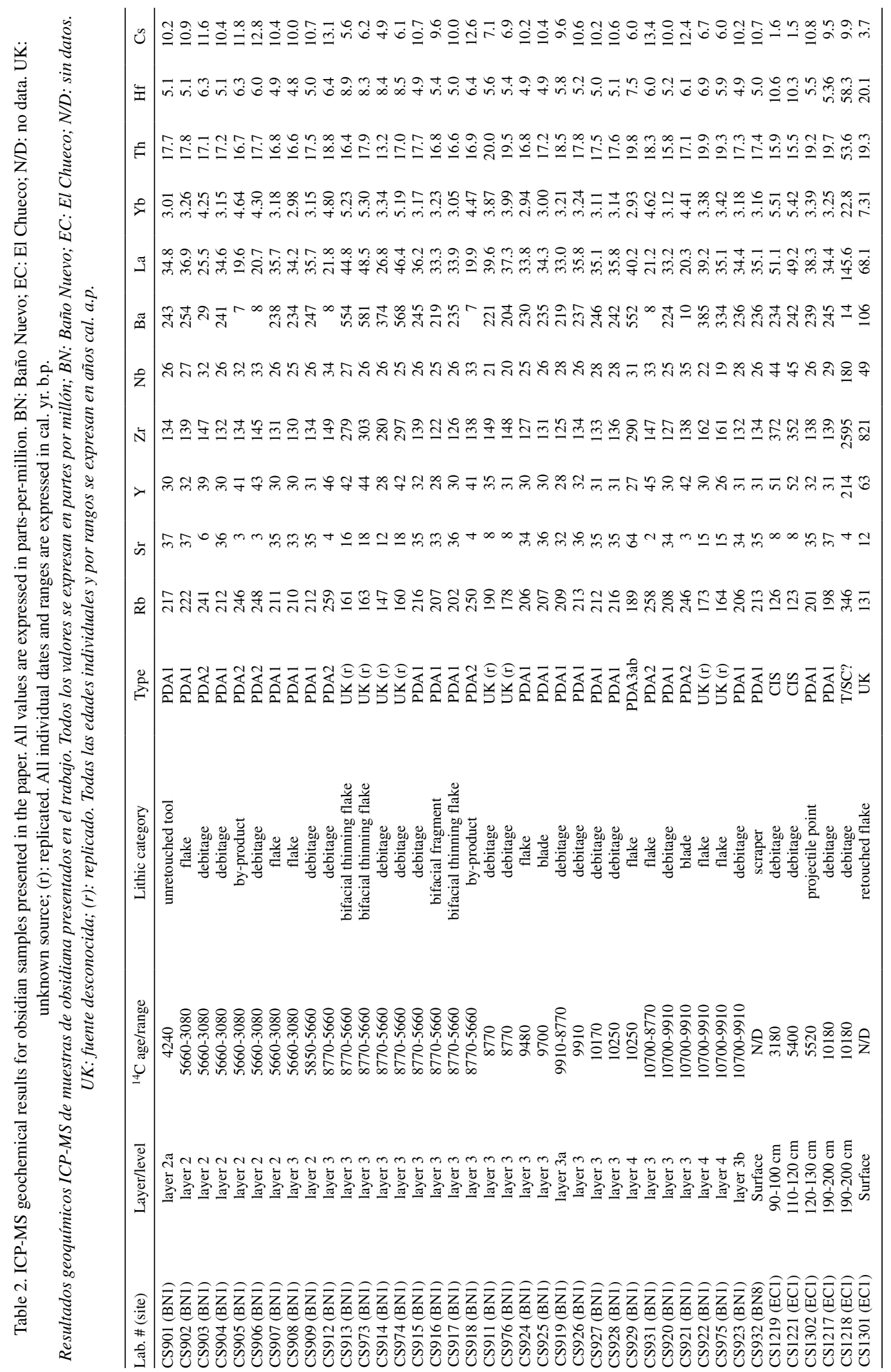




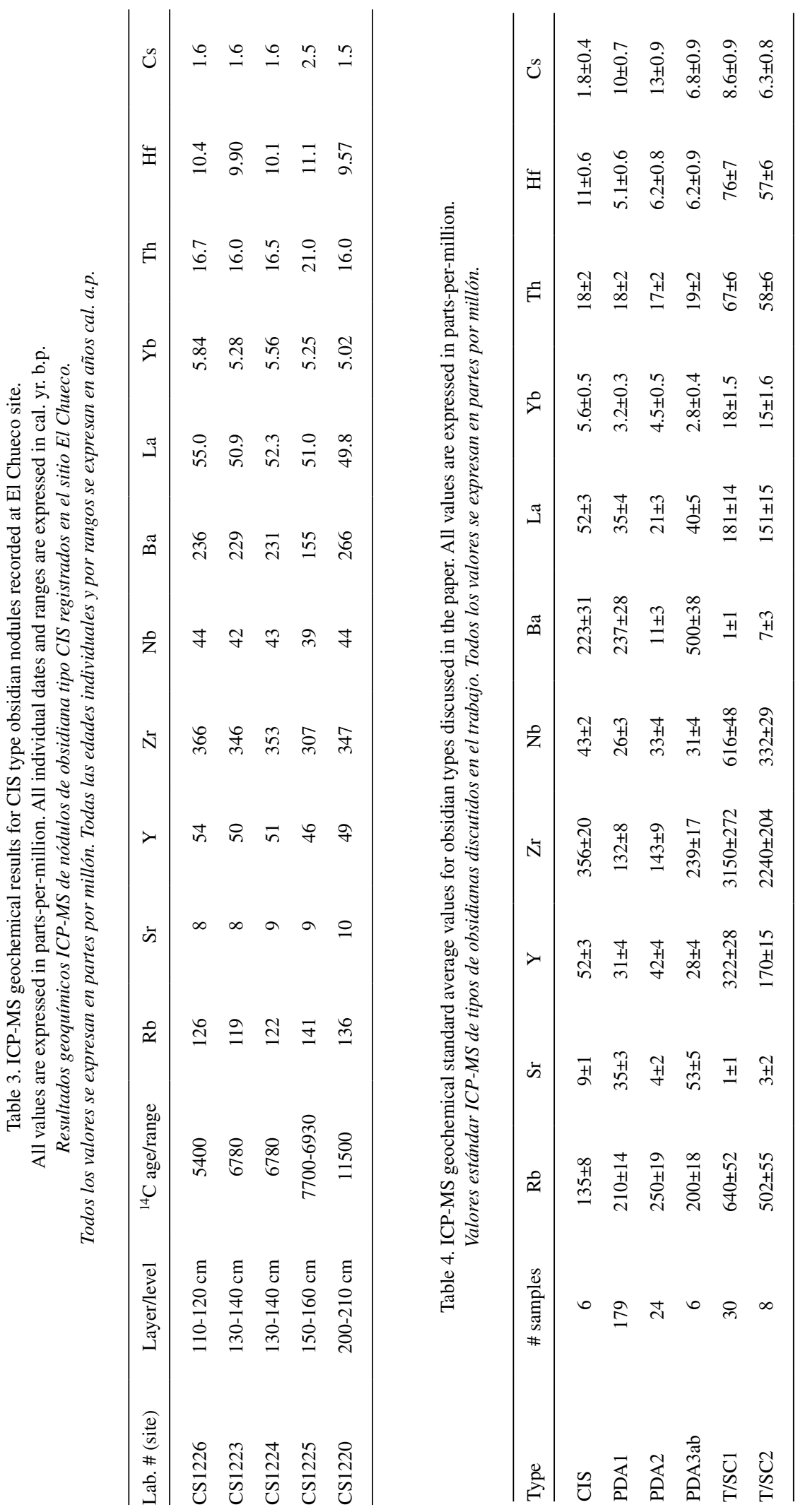


use, at both surface and stratigraphic sites, despite the ease of local procurement.

For Baño Nuevo site, sourcing obsidian analyses resulted in the identification of types exclusively procured at Pampa del Asador (PDA1, 2, 3ab). In four cases unknown types were identified (replicated and confirmed). Obsidian at Baño Nuevo occurs mainly as debitage, though also includes larger-sized flakes than in the case of El Chueco site. Also the lithic assemblage shows higher obsidian debitage frequencies (early: $\mathrm{n}=2,4.3 \%$; mid: $\mathrm{n}=144,12.7 \%$; and late component: $\mathrm{n}=11,5.4 \%$ ) especially during

Table 5. Obsidian types and chronological distribution at El Chueco and Baño Nuevo sites.

Tipos de obsidianas en los sitios El Chueco y Baño Nuevo y su distribución cronológica.

\begin{tabular}{|c|c|c|c|c|c|c|c|}
\hline \multirow{2}{*}{ Sites; ${ }^{14} \mathrm{C}$ ages/ranges } & \multicolumn{6}{|c|}{ Obsidian types } & \multirow[b]{2}{*}{ Total } \\
\hline & UK & CIS & T/SC? & PDA1 & PDA2 & PDA3ab & \\
\hline \multicolumn{8}{|l|}{ El Chueco } \\
\hline Surface & 1 & & & & & & 1 \\
\hline 3.180 cal. yr. b.p. & & 1 & & & & & 1 \\
\hline 5.520-5.400 cal. yr. b.p. & & 1 & & 1 & & & 2 \\
\hline 10.180 cal. yr. b.p. & & & 1 & 1 & & & 2 \\
\hline
\end{tabular}

Baño Nuevo components

\begin{tabular}{|c|c|c|c|c|c|c|c|}
\hline Surface (Baño Nuevo 8) & & & & 1 & & & 1 \\
\hline late (5660-3080 cal. yr. b.p.) & & & & 5 & 3 & & 8 \\
\hline mid (8.770-5.660 cal. yr. b.p.) & 3 & & & 4 & 2 & & 9 \\
\hline early (10.700-8.770 cal. yr. b.p.) & 1 & & & 8 & 2 & 1 & 12 \\
\hline Total of both sites & 5 & 2 & 1 & 20 & 7 & 1 & 36 \\
\hline
\end{tabular}

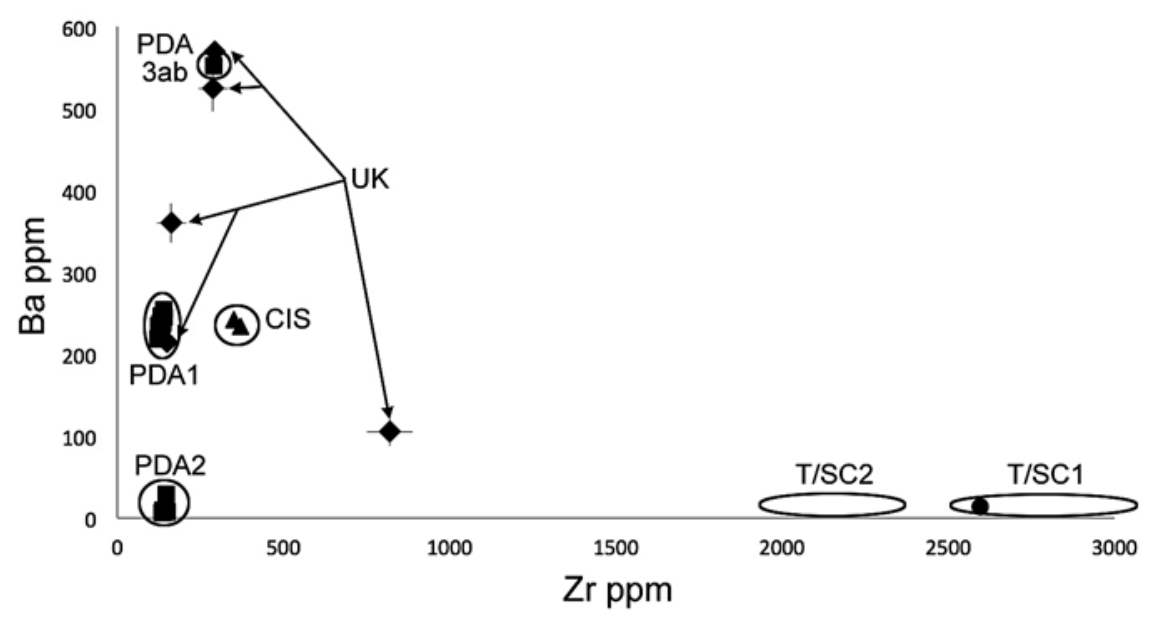

Figure 2. Plot of Ba versus $\mathrm{Zr}$ concentrations, in parts-per-million (ppm), for obsidian artifacts from El Chueco and Baño Nuevo. Error bars $( \pm 10 \%)$ are indicated for three samples from unknown (UK) sources. The analytical uncertainties for the others samples fall within the $95 \%$ confidence ellipses defining the fields (taken from Stern 2004, and Mendez et al. 2008-9) for the chemistry of the obsidian from these known sources (PDA1; PDA2; PDA3ab, CIS, T/SC1, and T/SC2).

Gráfico de concentraciones de Ba versus Zr en partes por millón (ppm) para artefactos de obsidiana de El Chueco y Baño Nuevo. Se indican los errores $( \pm 10 \%)$ para tres muestras de fuentes desconocidas (UK). Las incertidumbres analíticas para todas las otras muestras caen dentro de las elipses de $95 \%$ de confianza que definen los campos (obtenidos de Stern 2004 y Méndez et al. 2008-9) para la química de la obsidiana de estas fuentes conocidas (PDA1; PDA2; PDA3ab, CIS, T/SC1 y T/SC2). 


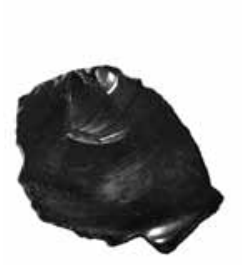

a.

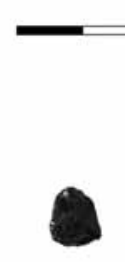

b.

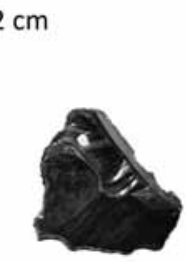

c.

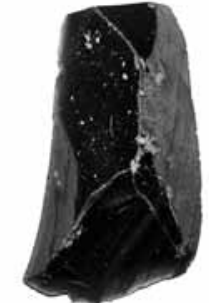

d.

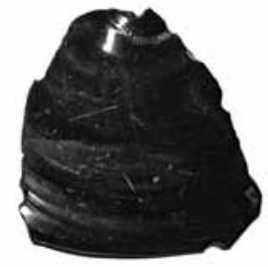

e.

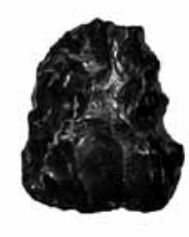

f.

Figure 3. Selected obsidian artifacts sampled for ICP-MS analysis, (a) CS90, (b) CS915, (c) CS920, (d) CS922/975, (e) CS924, and (f) CS1302; (a-e): Baño Nuevo 1, (f) El Chueco 1. All artifacts are PDA1, except CS922/975 which is from unknown source. Algunos artefactos de obsidiana muestreados para análisis de ICP-MS, (a) CS90, (b) CS915, (c) CS920, (d) CS922/975, (e) CS924 y (f) CS1302; (a-e): Baño Nuevo 1, (f) El Chueco 1. Todos los artefactos son PDA1, excepto CS922/975 que es de fuente desconocida.

the middle Holocene, which in this case argues in favor of direct procurement strategies. The site yields both middle and later stages in obsidian reduction sequences (based on the size and shape of flakes, and a $0.5 \%$ frequency of cortex in the evidences), and only two formal (i.e. curated) bifacial tools (one knife and one projectile point) for the middle Holocene component (García 2007). Unknown sources in the Baño Nuevo assemblage are limited to the early and middle Holocene components, thus suggesting that alternative less-known sources were probably abandoned or less used afterwards. The fact that geochemical analyses on surface materials within Aisén and in wider central-south Patagonia have not recorded these types previously corroborates this idea. Finally, the only analyzed sample from a surface site (BN8) 500 meters away from Baño Nuevo 1 also resulted in PDA1 type.

\section{Discussion}

Evidence presented here and elsewhere indicates that Pampa del Asador was the obsidian source most recurrently represented in the exotic raw material artifact distributions in central-south continental Patagonia (García-Herbst et al. 2007; Stern 1999). Although located at a relatively high-altitude (1100 masl), it constitutes a large $>50 \mathrm{~km}^{2}$ area (Rafael Goñi personal communication 2011) where highquality obsidian nodules, widely distributed by fluvial processes, and other resources are abundant (Espinosa and Goñi 1999). Recent research has pointed out lower-altitude more easy-accessible procurement locations to the east for this same obsidian (Belardi et al. 2006). These characteristics, along with its exceptional knapping quality, justify the preferential selection and long-distance transport it was subjected to. Considering a mid-point at the source, Baño Nuevo site is located $290 \mathrm{~km}$ distant, while El Chueco is $360 \mathrm{~km}$ away. These sites show a long-distance transport of this rock since at least 10,700 cal. yr. b.p., which is a comparable age as the evidence for the exploitation of this obsidian at the less distant site of Cerro Casa de Piedra 7 (Stern 1999), and younger than other long distant sites such as Cerro Tres Tetas (Paunero 2003; Stern 2004).

As distance from this location increased, and distance to the Somuncurá plateau, particularly the Sierra Negra source, decreased, making both procurement areas "relatively" equidistant, we observe the incorporation of northern sources, as shown by the Early Holocene evidence at El Chueco and from later surface sites in the environs (Méndez et al. 2008-9). Obsidian at the Somuncura plateau sources of Sierra Negra and Sacanana occur also as surface nodules widely distributed by fluvial processes (Stern et al. 2000). Recent studies of sites to the east of Aisén, in Chubut (Argentina), also confirm a distance dependent increase in the abundance of obsidian from Somuncurá plateau sources and decrease in the abundance of Pampa del Asador obsidian to the northeast (Stern et al. 2011). This implies that distance played a key-role in determining obsidian transport, and -answering our first question- it indirectly suggests that geochemical analyses on surface samples should be considered in building hypotheses for understanding earlier exotic rock transport.

The fact that Baño Nuevo yields exclusively obsidians from Pampa del Asador and has no evidence of types from the sources located to the north (despite no biogeographical barriers conditioned transit), further 
suggests that people occupying the site participated in mobility ranges linked to southern Patagonia, either by moving themselves or through exchange. Besides the obsidian evidence, mtDNA analyses on the Early Holocene human remains deposited at the site shows shared haplogroups (B and C) with southern sites around $52^{\circ} \mathrm{S}$ (Moraga et al. 2009).

Chronological data presented in this paper suggests Pampa del Asador obsidian source was utilized at areas near the eastern rim of the Andes at least since 10,700 cal. yr. b.p. These data, along with that produced at one terminal Pleistocene (Cerro Tres Tetas) and other Early Holocene sites with the same obsidian types such as Cerro Casa de Piedra 7, Chorrillo Malo 2, Cueva de las Manos and La Martita, further confirms the previously known fact that this source was the most recurrently used south of $42^{\circ} \mathrm{S}$.

Kelly and Todd (1988), studying the early peopling of North America, have suggested that human groups colonizing unfamiliar spaces, rather than orienting themselves towards localities, would have developed a technological orientation where the major concern were resources and their availability. This would have probably made individuals more selective regarding which aspects to consider while learning new landscapes (Kelly 2003). Once a high-quality lithic raw-material concentration was recognized as a potential source, this was transformed into a place where recurrent visits transformed it into a central spot from which mobility was organized (Gamble 1999). This scenario seems to be the case with Pampa del Asador source within central-south Patagonia. The paucity of obsidian evidence during the terminal Pleistocene and the posterior increase in frequency (both quantitative and in a site-bysite basis) suggests a cumulative -and probably long-term- process of human management of key-lithic resources and information flows among early settlers. Answering our second question, data from the sites discussed here and elsewhere shows a continuous presence of Pampa del Asador obsidian after the Early Holocene (García-Herbst et al. 2007; Stern 2004), thus suggesting that the mid-Holocene interruption of obsidian transport might have been limited to some regional datasets, as the one described for Fell's cave and Pali Aike (Stern 2000). This remarkably stable pattern of longdistance obsidian transport requires further testing with obsidian samples from additional well-dated multicomponent sites.

\section{Conclusions}

Borrero (1994-5) has developed an ecological model for understanding the peopling of new regions using the case of Patagonia. Following this model, Borrero and Franco (1997) focused on a series of expectations, including the lithic behavior. Among them was that exploratory occupations within a region would most probably rely on locally available lithic resources independently of their quality. Data presented by the authors suggests a dominant majority of local raw material for the earliest occupations and an increase in variability only in younger deposits (Borrero and Franco 1997). For instance, geochemical data on undated obsidian fishtail projectile points (appropriate terminal Pleistocene chronological markers in the region) from Los Amigos 2 locality suggests an early use of only local sources around the Somuncurá plateau (Miotti et al. 2010). In the Aisén region, limited evidence dated at 11,500 cal. yr. b.p. at El Chueco shows only one shortlived discarded tool, and this tool is made of local microgranodiorite (Reyes et al. 2007), but by the onset of the Holocene, exotic obsidian and other high-quality siliceous raw materials appear in a series of recurrent occupations at both El Chueco and Baño Nuevo sites (García 2007; Méndez et al. 2011). Thus these observations would be consistent with the suggestion of Borrero and Franco (1997) that the early recognition of sources was primarily coupled with short-distance transport.

After the initial latest Pleistocene regional exploration, recurrent long-distance transport of obsidians beginning in the Early Holocene is supported at El Chueco and Baño Nuevo, where obsidian appears at 10,180 cal. yr. b.p. in the former, and 10,700 cal. yr. b.p. in the latter. These data gathered for the Early Holocene occupational levels in Aisén shows that by this time we are not facing an exploratory stage of the peopling model, but rather the following stage, -colonization-, where recurrent mobility circuits (expressed through raw material transport) would have been established (Borrero 1994-5). Thus, answering our third question, recurrent long-distance obsidian circulation routes originated during or immediately after the onset of the Holocene, as suggested by data presented here and sites elsewhere in centralsouth Patagonia (Civalero and Franco 2003; Stern 1999, 2004). 
Acknowledgements: FONDECYT 1090027 grant. We acknowledge the following colleagues for their useful help and suggestions: Ramiro Barberena, Christian García, Rafael Goñi, Amalia
Nuevo Delaunay, Lorena Sanhueza, and four anonymous reviewers. We thank Estancia Río Cisnes and Estancia Baño Nuevo for granting permissions for our archaeological research.

\section{References Cited}

Barberena, R., A. Hajduk, A.F. Gil, G.A. Neme, V. Durán, M. Glascock, M. Giesso, K. Borrazzo, M.P. Pompei, M.L. Salgán, V. Cortegoso, G. Villarosa and A. Rughini 2010. Obsidian in the south-central Andes: Geological, geochemical, and archaeological assessment of north Patagonian sources (Argentina). Quaternary International 245:25-36.

Belardi, J., P. Tiberi, C. Stern and A. Súnico 2006. Al Este del Cerro Pampa: ampliación del área de disponibilidad de obsidiana de la Pampa del Asador (Provincia de Santa Cruz). Intersecciones en Antropología 7:27-36.

Bellelli, C. and F. Pereyra 2002. Análisis geoquímicos de obsidiana. Distribuciones, fuentes y artefactos arqueológicos en el Noroeste del Chubut (Patagonia argentina). Werken 3:99-118.

Borrero, L.A. 1994-5. Arqueología de la Patagonia. Palimpsesto Revista de Arqueología 4:9-69.

Borrero, L.A. and N. Franco 1997. Early Patagonian huntergatherers: Subsistence and technology. Journal of Anthropological Research 53:219-239.

Bronk Ramsey, C. 2009. Bayesian analysis of radiocarbon dates. Radiocarbon 51:337-360.

Civalero, M. and N. Franco 2003. Early human occupations in Western Santa Cruz Province, Southernmost South America. Quaternary International 109-110:77-86.

Espinosa, S. and R. Goñi 1999. Viven: Una fuente de obsidiana en la provincia de Santa Cruz. Actas de las III Jornadas de Arqueología de la Patagonia: Soplando en el Viento, edited by J. Belardi, P. Fernández, R. Goñi, A. Guráieb and M. De Nigris, pp. 177-188. INAPL, Buenos Aires.

Favier Dubois, C., C. Stern and M. Cardillo 2009. Caracterización de la distribución y tipos de obsidiana presentes en la costa rionegrina, Argentina. In Arqueología de la Patagonia. Una Mirada desde el Último Confín, edited by M. Salemme, F. Santiago, M. Álvarez, E. Piana, M. Vásquez and E. Mansur, pp. 349-359. Editorial Utopías, Ushuaia.

Gamble, C. 1999. The Palaeolithic Societies of Europe. Cambridge University Press, Cambridge.

García, C. 2007. Conjuntos líticos y estrategias tecnológicas de las ocupaciones humanas de la cuenca de Baño Nuevo-1 (XI Región de Aisén, Chile). In Arqueología de Fuego-Patagonia. Levantando Piedras, Desenterrando Huesos... Develando Arcanos, edited by F. Morello, M. Martinic, A. Prieto and G. Bahamonde, pp. 493-502. CEQUA, Punta Arenas.

García-Herbst, A., C. Stern, H. Neff, J. Lanata and L. García 2007. Laser ablation ICP-MS analysis of black obsidian nodules from Pampa del Asador and archaeological samples from southernmost Patagonia (Santa Cruz Province). In Arqueología de Fuego-Patagonia. Levantando Piedras,
Desenterrando Huesos... Develando Arcanos, edited by F. Morello, M. Martinic, A. Prieto and G. Bahamonde, pp. 235246. CEQUA, Punta Arenas.

Gómez Otero, J. and C. Stern 2005. Circulación, intercambio y uso de obsidianas en la costa de la provincia del Chubut (Patagonia argentina), durante el Holoceno Tardío. Intersecciones en Antropología 6:93-108.

Kelly, R. 2003. Colonization of new land by hunter-gatherers: Expectations and implications based on ethnographic data. In Colonization of Unfamiliar Landscapes: The Archaeology of Adaptation, edited by M. Rockman and J. Steele, pp. 44-58. Routledge, London.

Kelly, R. and L. Todd 1988. Coming into the country: Early Paleoindian hunting and mobility. American Antiquity 53:231-244.

Markgraf, V., C. Withlock and S. Haberle 2007. Vegetation and fire history during the last 18,000 cal yr B.P. in Southern Patagonia: Mallín Pollux, Coyhaique, Province Aisén (4541'30's, 7150’30' W, 640m elevation). Palaeogeography, Palaeoclimatology, Palaeoecology 254:429-507.

McCormac, F.G., A.G. Hogg, P.G. Blackwell, C.E. Buck, T.F.G. Higham and P.J. Reimer 2004. SHCal04 Southern Hemisphere calibration, 0-11.0 cal kyr BP. Radiocarbon 46:1087-1092.

Meltzer, D. 1989. Was stone exchanged among eastern north american paleoindians? In Eastern Paleoindian Lithic Resource Use, edited by C. Ellis and J. Lothrop, pp. 11-39. Westview Press, Boulder.

Mena, F. 2009. Aves en cueva Baño Nuevo. In Zooarqueología y Tafonomía en el Confín del Mundo, edited by P. López, I. Cartajena, C. García and F. Mena, pp. 59-72. UISEK, Santiago.

Mena, F., V. Lucero, O. Reyes, V. Trejo and H. Velásquez 2000. Cazadores tempranos y tardíos en la cueva Baño Nuevo-1, margen occidental de la estepa centropatagónica (XI Región de Aisén, Chile). Anales del Instituto de la Patagonia, Serie Ciencias Humanas 28:173-195.

Mena, F. and T. Stafford 2006. Contexto estratigráfico y fechación directa de esqueletos humanos del Holoceno temprano en Cueva Baño (Patagonia Central, Chile). $2^{\circ}$ Simposio Internacional del Hombre Temprano en América, edited by J. Jiménez, S. González, J. Pompa and F. Ortíz, pp. 139-154. INAH, Ciudad de México.

Méndez, C. 2004. Movilidad y manejo de recursos líticos de tres valles andinos de Patagonia centro occidental. In Contra Viento y Marea. Arqueología de Patagonia, edited by M. Civalero, P. Fernández and G. Guráieb, pp. 135-147. INAPL, Buenos Aires.

Méndez, C. and O. Reyes 2008. Late Holocene human occupation of Patagonian forests: a case study at Cisnes River basin $\left(44^{\circ} \mathrm{S}\right.$, Chile). Antiquity 82:560-570. 
Méndez, C., O. Reyes, and A. Maldonado 2010. The last 1500 years of human-climate interactions in Aisén: An overview on regional information. Paper presented at the II International Symposium: Reconstructing Climate Variations in South America and the Antarctic Peninsula over the last 2000 years, Valdivia.

Méndez, C., O. Reyes, A. Nuevo Delaunay, V. Trejo, R. Barberena and H. Velásquez 2011. Ocupaciones humanas en la margen occidental de Patagonia Central: eventos de poblamiento en Alto Río Cisnes. Magallania 39:223-242.

Méndez, C., C. Stern and O. Reyes 2008-9. Transporte de obsidianas a lo largo de los Andes de Patagonia Central (Aisén, Chile). Cazadores-Recolectores del Cono Sur 3:51-68.

Miotti, L., D. Hermo and E. Terranova 2010. Fishtail points, first evidence of Late-Pleistocene hunter-gatherers in Somuncurá plateau (Río Negro Province, Argentina). Current Research in the Pleistocene 27:22-24.

Molinari, R. and S. Espinosa 1999. Brilla tú, diamante "loco"... Actas de las III Jornadas de Arqueología de la Patagonia: Soplando en el Viento, edited by J. Belardi, P. Fernández, R. Goñi, A. Guráieb and M. De Nigris, pp. 189-198. INAPL, Buenos Aires.

Moraga, M., F. Mena, O. Reyes, G. Barrientos, R. Goñi, N. Franco and L. Borrero 2009. Linajes mitocondriales fundadores en restos humanos prehistóricos de Patagonia y Tierra del Fuego. Paper presented at the Novenas Jornadas Nacionales de Antropología Biológica, Puerto Madryn.

Morello, F., M. San Román and A. Prieto 2004. Obsidiana verde en Fuego-Patagonia: distribución y estrategias tecnológicas. In Contra Viento y Marea. Arqueología de Patagonia, edited by M. Civalero, P. Fernández and G. Guráieb, pp. 149-165. INAPL, Buenos Aires.

Morello, F., M. San Román, A. Prieto and C. Stern 2001. Nuevos antecedentes para una discusión arqueológica en torno a la obsidiana verde en Patagonia meridional. Anales del Instituto de la Patagonia, Serie Ciencias Humanas 29:129-148.

Paunero, R. 2003. The Cerro Tres Tetas (C3T) locality in the Central Plateau of Santa Cruz Province, Patagonia, Argentina. In Where the South Winds Blow. Ancient Evidence of Paleo South Americans, edited by: L. Moitti, M. Salemme and N. Flegenheimer, pp. 133-140. Center for the Study of the First Americans, College Station.

Reimer, P.J., M.G.L. Baillie, E. Bard, A. Bayliss, J.W. Beck, P.G. Blackwell, C. Bronk Ramsey, C.E. Buck, G.S. Burr, R.L. Edwards, M. Friedrich, P.M. Grootes, T.P. Guilderson, I. Hajdas, T.J. Heaton, A.G. Hogg, K.A. Hughen, K.F. Kaiser, B. Kromer, F.G. McCormac, S.W. Manning, R.W. Reimer, D.A. Richards, J.R. Southon, S. Talamo, C.S.M. Turney, J. van der Plicht, and C.E. Weyhenmeyer 2009. IntCa109 and Marine09 radiocarbon age calibration curves, 0-50,000 years cal BP. Radiocarbon 51:1111-1150.

Reyes, O., C. Méndez, A. Maldonado, H. Velásquez, V. Trejo, M. Cárdenas and A.M. Abarzúa 2009. Uso del espacio de cazadores recolectores y paleoambiente Holoceno en el valle del río Cisnes, región de Aisén, Chile. Magallania 37:91-107.

Reyes, O., C. Méndez, V. Trejo and H. Velásquez 2007. El Chueco 1: un asentamiento multicomponente en la estepa occidental de Patagonia Central (11400 a 2700 años cal ap., $\sim 44^{\circ}$ S). Magallania 35:61-74.

Saadat, S. and C. Stern 2011. Petrochemistry and genesis of olivine basalts from small monogenetic parasitic cones of Bazman stratovolcano, Makran arc, southeastern Iran. Lithos 125: 609-617.

San Román, M. and A. Prieto 2004. (Dis)continuidad del uso de obsidiana verde entre poblaciones de adaptación marítima del mar de Otway y Estrecho de Magallanes. In Contra Viento y Marea. Arqueología de Patagonia, edited by M. Civalero, P. Fernández and G. Guráieb, pp. 571-580. INAPL, Buenos Aires.

Stern, C. 1999. Black obsidian from central-south Patagonia; chemical characteristics, sources and regional distribution of artifacts. Actas de las III Jornadas de Arqueología de la Patagonia: Soplando en el Viento, edited by J. Belardi, P. Fernández, R. Goñi, A. Guráieb and M. De Nigris, pp. 221-234. INAPL, Buenos Aires.

- - - 2000. Fuentes de los artefactos de obsidiana en los sitios arqueológicos de las cuevas de Pali Aike y Fell y Cañadón La Leona, en Patagonia Austral. Anales del Instituto de la Patagonia, Serie Ciencias Humanas 28:251-263.

- - - 2004. Obsidian in southern Patagonia: review of the current information. In Contra Viento y Marea. Arqueología de Patagonia, edited by M. Civalero, P. Fernández and G. Guráieb, pp. 167-176. INAPL, Buenos Aires.

Stern, C. and N. Franco 2000. Obsidiana gris verdosa veteada de la cuenca superior del río Santa Cruz, extremo sur de la Patagonia. Anales del Instituto de la Patagonia, Serie Ciencias Humanas 28:265-273.

Stern, C., J. Gómez Otero and J. Belardi 2000. Características químicas, fuentes potenciales y distribución de diferentes tipos de obsidianas en el norte de la provincia del Chubut, Patagonia Argentina. Anales del Instituto de la Patagonia, Serie Ciencias Humanas 28:275-290.

Stern, C., X. Navarro and J. Muñoz 2002. Obsidiana gris translúcida del volcán Chaitén en los sitios arqueológicos de Quilo (Isla Grande de Chiloé) y Chanchán (X Región) Chile, y obsidiana del Mioceno en Chiloé. Anales del Instituto de la Patagonia, Serie Ciencias Humanas 30:167-174.

Stern, C., C. Pérez de Micou, A. Castro and C. Méndez 2011. Circulación de obsidianas en Patagonia Central-Sur entre 44 y $46^{\circ} \mathrm{S}$ (Chubut, Argentina, y Coyhaique y Alto Cisnes, Chile). Paper presented at the VIII Jornadas de Arqueología de la Patagonia, Malargüe.

Stern, C. and A. Prieto 1991. Obsidiana verde de los sitios en los alrededores del mar de Otway, Magallanes, Chile. Anales del Instituto de la Patagonia, Serie Ciencias Humanas 20:139-144.

Velásquez, H. and F. Mena 2006. Distribuciones óseas de ungulados en la Cueva Baño Nuevo-1 (XI Región, Chile): un primer acercamiento. Magallania 34:91-106.

Villa-Martínez, R., P. Moreno and M. Valenzuela 2011. Deglacial and postglacial vegetation changes on the eastern slopes of the central Patagonian Andes ( $\left.47^{\circ} \mathrm{S}\right)$. Quaternary Science Reviews 32:86-99. 
